\title{
HUBUNGAN ANTARA RIWAYAT PENYAKIT INFEKSI DENGAN STATUS GIZI PADA ANAK BATITA DI DESA MOPUSI KECAMATAN LOLAYAN KABUPATEN BOLAANG MONGONDOW
}

\author{
${ }^{1}$ Maya S. Putri \\ ${ }^{2}$ Nova Kapantow \\ ${ }^{3}$ Shirley Kawengian \\ ${ }^{1}$ Kandidat Skripsi Fakultas Kedokteran Universitas Sam Ratulangi Manado \\ ${ }^{2}$ Bagian Gizi Fakultas Kedokteran Universitas Sam Ratulangi Manado \\ Email: mputri11_274@yahoo.com
}

\begin{abstract}
Infection is commonly found in toddlers. One of the causes of infection is the poor nutritional status. This study aimed to determine the relationship between histories of infectious diseases and the toddlers' nutritional status in the Mopusi village Lolayan, Bolaang Mongondow. This study used a cross sectional approach. Respondents were 90 women who had toddlers (aged less than 3 years) with histories of infectious diseases from September 2014 until December 2014. Data were analyzed by using SPSS. There were 26 toddlers (28.9\%) that had histories of infectious diseases. The results of nutritional status were as follows: according to the BMI/A the most (68.9\%) were normal and the lowest (5.6\%) was very thin; BW/A the most (73.3\%) had good nutrition and the lowest nutrition one child (1.1\%); H/A the most (45.6\%) were normal and the lowest height 3 children (3.3\%); $\mathrm{W} / \mathrm{H}$ the most were normal (78.9\%) and the lowest very thin 1 child $(1.1 \%)$. The correlations of nutritional status and infectious diseases $(\alpha=0.05)$ were as follows: BMI/A showed correlation coefficient (r) 0.046 and $p=0668$; W/A showed (r) -0118 and $\mathrm{p}=0268 ; \mathrm{H} / \mathrm{A}$ showed $(\mathrm{r}) 0.59$ and $\mathrm{p}=0.580$; W/H showed $(\mathrm{r}) 0.095$ and $\mathrm{p}=0.372$. Conclusion: There was no correlation between nutritional status (according to BMI/A, W/A, H/A, and W/H) and histories of infectious diseases among children aged less than 3 years in the Mopusi village, Lolayan, Bolaang Mongondow.
\end{abstract}

Keywords: nutritional status, history of infectious diseases

\begin{abstract}
Abstrak: Infeksi merupakan salah satu penyakit yang sering terjadi pada anak batita; salah satu penyebabnya ialah status gizi kurang. Penelitian ini bertujuan untuk mengetahui hubungan antara riwayat penyakit infeksi dengan status gizi pada anak batita di Desa Mopusi Kecamatan Lolayan Kabupaten Bolaang Mongondow. Penelitian ini menggunakan metode korelasi dengan pendekatan potong lintang. Responden ialah ibu yang memliki batita dengan riwayat penyakit infeksi sebanyak 90 orang di Desa Mopusi pada bulan September 2014-Desember 2014. Data dianalisis menggunakan SPSS. Hasil penelitian memperlihatkan riwayat penyakit infeksi ditemukan pada 26 batita (28,9\%). Status gizi menurut IMT/U terbanyak normal 62 anak (68,9\%) dan terendah sangat kurus 5 anak (5,6\%); BB/U terbanyak gizi baik 66 anak (73,3\%) dan terendah gizi lebih 1 anak (1,1\%); TB/U terbanyak normal 41 anak (45,6\%) dan terendah tinggi 3 anak (3,3\%); BB/TB terbanyak normal 71 anak (78,9\%) terendah sangat kurus 1 anak (1,1\%). Mengenai hubungan status gizi dengan penyakit infeksi $(\alpha=0,05)$ didapatkan: untuk status gizi IMT/U (r) 0,046 dan $\mathrm{p}$ $=0,668$; status gizi BB/U (r) $-0,118$ dan $\mathrm{p}=0,268$; status gizi $(\mathrm{TB} / \mathrm{U})(\mathrm{r}) 0,59$ dan $\mathrm{p}=0,580$; dan status gizi (BB/TB) (r) 0,095 dan $\mathrm{p}=0,372$. Simpulan: Tidak terdapat hubungan antara status gizi (IMT/U, BB/U, TB/U, dan BB/TB) dengan penyakit infeksi pada anak umur 1-3 tahun di Desa Mopusi Kecamatan Loloyan Kabupaten Bolaang Mongondow Induk.
\end{abstract}

Kata kunci: status gizi, riwayat penyakit infeksi, batita 
Status gizi adalah keadaan tubuh sebagai akibat konsumsi makanan dan penggunaan zat-zat gizi yang dibedakan atas status gizi buruk, kurang, baik, dan lebih. Secara klasik kata gizi hanya dihubungkan dengan kesehatan tubuh, yaitu untuk menyediakan energi, membangun, dan memelihara jaringan tubuh, serta mengatur prosesproses kehidupan dalam tubuh. Saat ini kata gizi mempunyai pengertian lebih luas di samping untuk kesehatan, gizi dikaitkan dengan potensi ekonomi seseorang, karena gizi berkaitan dengan perkembangan otak, kemampuan belajar, dan produktivitas kerja. Oleh karena itu, di Indonesia yang sekarang sedang membangun, faktor gizi di samping faktor-faktor lain dianggap penting untuk memacu pembangunan, khususnya yang berkaitan dengan pengembangan sumber daya manusia berkualitas. $^{1}$

Infeksi merupakan salah satu penyakit yang sering terjadi pada anak batita, dimana salah satu penyebab infeksi adalah keadaan status gizi batita yang kurang, yang secara langsung di pengaruhi oleh kurangnya pengetahuan Ibu khususnya tentang makanan yang bergizi. ${ }^{2}$ Kecukupan gizi yang baik pada anak akan meningkatkan daya tahan terhadap penyakit, anak yang mengalami kurang gizi akan mudah terkena penyakit terutama penyakit infeksi. Seperti kita ketahui, bahwa hubungan infeksi dengan status gizi sangat erat, demikian juga sebaliknya. ${ }^{3}$

Air susu ibu (ASI) paling cocok untuk memenuhi kebutuhan bayi dalam segala hal, baik itu karbohidrat dalam ASI berupa laktosa, kandungan vitamin dan mineralnya yang banyak, perbandingan antara kalsiumfosfat sebesar 2:1 yang merupakan kondisi ideal bagi penyerapan kalsium. ASI juga mengandung zat anti infeksi yang terdapat dalam kolostrum. Kolostrum adalah susu yang keluar pertama kali pada ASI, berwarna kental kekuningan dan kaya akan zat antibodi. ${ }^{4}$ Penyakit infeksi dan hal penting yang harus di dapatkan setiap anak pada awal kehidupan adalah imunitas terhadap berbagai organisme penyebab penyakit. Mekanisme imunologi pada anak
- anak pada dasarnya sama dengan pada orang dewasa namun belum berkembang sempurna saat lahir. Imunitas selular sudah efektif sejak lahir: selama 2 atau 3 tahun pertama, jumlah sel darah putih relatif tinggi, limfosit lebih banyak dari pada polimorfik dalam sirkulasi darah. ${ }^{5}$

Penyakit infeksi masih menjadi masalah kesehatan anak di Indonesia. Terbukti, angka kesakitan dan angka kematian anak akibat penyakit tersebut masih cukup tinggi. Daya tahan tubuh balita yang masih rendah mengakibatkan anak mudah sekali terserang berbagai penyakit infeksi. ${ }^{6}$

\section{METODE PENELITIAN}

Penelitian ini menggunakan metode potong lintang. Penelitian ini dilakukan sejak September 2014 - Desember 2014 di Desa Mopusi Kecamatan Lolayan Kabupaten Bolaang Mongondow Induk. Populasi penelitian ialah anak berumur 1-3 tahun.

Dalam penelitian ini digunakan lembar persetujuan penelitian dan kuesioner, weighing Scale bayi dengan tingkat ketelitian 0,1 kg, serta alat ukur tinggi badan (microtois) dengan ketelitian 0,1 cm.

Analisis data univariat digunakan untuk mengambarkan karakteristik ibu yang terdiri dari umur ibu, pendidikan ibu, pekerjaan ibu dan penghasilan keluarga, Karakteristik anak terdiri dari umur anak, jenis kelamin anak, ururtan anak keberapa, jumlah anggota keluarga, pengetahuan gizi, dan status gizi anak. Analisis bivariat dilakukan untuk melihat hubungan antara pengetahuan ibu tentang gizi degan status gizi anak. Data dianalisis dengan menggunakan SPSS dengan menggunakan uji Spearman's rho.

\section{HASIL PENELITIAN}

\section{Gambaran Umum Tempat Penelitian}

Desa Mopusi terletak di Kecamatan Lolayan Kabupaten Bolaang Mongondow Induk dengan luas wilayah $7,93 \mathrm{~km}^{2}$.

Penduduk desa Mopusi seluruhnya berjumlah 2.284 jiwa dengan penduduk laki-laki sebanyak 1174 jiwa dan 
perempuan sebanyak 1110 jiwa. Penduduk desa Mopusi yang belum atau tidak tamat sekolah yaitu sebanyak 400 jiwa; berpendidikan Sekolah Dasar 1181 jiwa; Sekolah Menengah Pertama 375 jiwa; Sekolah Menengah Umum 65 jiwa; dan Perguruan Tinggi 7 jiwa. Sebagian penduduk desa Mopusi bekerja sebagai pekerja tambang dan petani.

\section{Karakteristik Sampel Penelitian}

Berdasarkan hasil penelitian didapatkan karakteristik sampel yang terdiri dari jenis kelamin, umur batita, umur ibu, anak ke, jumlah keluarga, pekerjaan ayah, pekerjaan ibu, pendidikan ayah, pendidikan ibu, penghasilan rata-rata ayah, dan penghasilan rata- rata ibu (Tabel 1).

Tabel 1. Distribusi Responden terhadap Karakteristik Sampel

\begin{tabular}{|c|c|c|}
\hline $\begin{array}{c}\text { Karakteristik } \\
\text { Reponden }\end{array}$ & $\mathrm{n}$ & $\%$ \\
\hline \multicolumn{3}{|l|}{ Jenis Kelamin } \\
\hline - Laki - laki & 38 & 42,2 \\
\hline - Perempuan & 52 & 57,8 \\
\hline \multicolumn{3}{|l|}{ Umur Batita } \\
\hline - 12 - 19 bulan & 42 & 46,7 \\
\hline - 20 - 28 bulan & 36 & 40 \\
\hline - $29-36$ bulan & 12 & 13,3 \\
\hline \multicolumn{3}{|l|}{ Anak Ke } \\
\hline-1 & 52 & 57,8 \\
\hline-2 & 21 & 23,3 \\
\hline-3 & 12 & 13,3 \\
\hline-4 & 4 & 4,4 \\
\hline-5 & 1 & 1,1 \\
\hline \multicolumn{3}{|l|}{ Jumlah Keluarga } \\
\hline - 3-4 orang & 57 & 63,3 \\
\hline$-5-6$ orang & 31 & 34,4 \\
\hline$-7-8$ orang & 2 & 2,2 \\
\hline \multicolumn{3}{|l|}{ Umur Ibu } \\
\hline - $15-25$ tahun & 64 & 71 \\
\hline - $26-35$ tahun & 25 & 27,8 \\
\hline - > 35 tahun & 1 & 1,1 \\
\hline \multicolumn{3}{|l|}{ Pekerjaan Ibu } \\
\hline - IRT & 78 & 86,7 \\
\hline - Mahasiswi/ & 2 & 2,2 \\
\hline pelajar & 3 & 3,3 \\
\hline - Pedagang & 1 & 1,1 \\
\hline - Perawat Gigi & 4 & 4,4 \\
\hline - Petani & 1 & 1,1 \\
\hline $\begin{array}{l}\text { - Sekolah } \\
\text { - Tambang }\end{array}$ & 1 & 1,1 \\
\hline
\end{tabular}

\begin{tabular}{lcc}
\hline Pendidikan Ibu & & \\
- SD & 37 & 41,1 \\
- SMP & 16 & 17,8 \\
- SMA & 34 & 37,8 \\
- PT & 3 & 3,3 \\
\hline Pekerjaan Ayah & & \\
- Mahasiswa & 1 & 1,1 \\
- Petani & 37 & 41,1 \\
- PNS & 8 & 8,9 \\
- Sekolah & 1 & 1,1 \\
- Tambang & 36 & 40 \\
- Wiraswasta & 7 & 7,8 \\
\hline Pendidikan Ayah & & \\
- SD & 28 & 31,1 \\
- SMP & 15 & 16,7 \\
- SMA & 39 & 43,3 \\
- PT & 8 & 8,9 \\
\hline Penghasilan Rata & & \\
- Rata Keluarga & & \\
- tidak ada & 14 & 15,6 \\
- < 1 juta & 21 & 23,3 \\
- 1 - 3 juta & 47 & 52,2 \\
- > 3 juta & 1 & 1,1 \\
\hline
\end{tabular}

Sampel penelitian yaitu anak umur 1- 3 tahun di Desa Mopusi Kecamatan Loloyan kabupaten Bolaang Mongondow Induk yang berjumlah 90 anak. Berdasarkan jenis kelamin, anak laki-laki lebih banyak dari pada perempuan. Laki-laki 38 batita (42,2\%). Di desa Mopusi anak usia 12-19 bulan yang terbanyak, 42 batita (46,7\%). Rata-rata umur ibu yang telah memiliki anak 15-25 tahun yaitu 64 ibu (71\%).

Umumnya ibu memiliki pekerjaan sebagai Ibu Rumah Tangga (IRT) sebanyak 78 orang $(86,7 \%)$ dan ayah sebagai petani 37 orang $(41,1 \%)$. Rata-rata penghasilan keluarga 1-3 juta (47 orang; 52,2\%).

\section{Gambaran riwayat penyakit infeksi}

Gambaran riwayat penyakit infeksi pada anak dalam 1 bulan terakhir dapat di kategorikan iya dan tidak, dimana 26 batita (28,9\%) masuk kategori iya dan 64 batita (71,1\%) masuk kategori tidak (Tabel 2).

Tabel 2. Gambaran Riwayat Penyakit Infeksi dalam 1 Bulan Terakhir

\begin{tabular}{ccc}
\hline $\begin{array}{c}\text { Riwayat } \\
\text { Penyakit Infeksi }\end{array}$ & $\mathrm{N}$ & $\%$ \\
\hline ISPA & 67 & 74,40 \\
Diare & 67 & 74,40 \\
Pneumoni & 36 & 40,00 \\
\hline
\end{tabular}


Tabel 3 memperlihatkan gambaran mengenai jenis kelamin dan pengaruhnya terhadap riwayat penyakit infeksi. Jumlah anak laki-laki yang memiliki riwayat penyakit infeksi selama satu bulan terakhir sebanyak 13 dari total 38 anak laki-laki. Anak perempuan yang memiliki riwayat penyakit infeksi selama 1 bulan terakhir sebanyak 12 dari total 52 anak perempuan.

Tabel 3. Gambaran Mengenai Jenis Kelamin dan Pengaruhnya Distribusi Subjek Terhadap Riwayat Penyakit Infeksi Menurut Jenis Kelamin

\begin{tabular}{|c|c|c|c|c|c|c|}
\hline & & $\begin{array}{c}\text { Riwayat } \\
\text { penyakit } \\
\text { infeksi }\end{array}$ & & & & \\
\hline $\begin{array}{c}\text { Jenis } \\
\text { Kelamin }\end{array}$ & Iya & $\%$ & Tidak & $\%$ & Total & $\%$ \\
\hline $\mathrm{P}$ & 12 & 13,3 & 40 & 44,4 & 52 & 57,7 \\
\hline $\mathrm{L}$ & 13 & 14,4 & 25 & 27,8 & 38 & 42,2 \\
\hline Jumlah & 25 & & 65 & & 90 & \\
\hline
\end{tabular}

\section{Gambaran Status Gizi Anak Batita Menurut IMT/U, BB/U, TB/U, BB/TB}

(Tabel 4)

Tabel 4. Distribusi Subjek Berdasarkan Status Gizi

\begin{tabular}{lcc}
\hline \multicolumn{1}{c}{ Kategori } & & \\
\multicolumn{1}{c}{ Status Gizi } & $\mathrm{n}$ & $\%$ \\
\hline IMT/U & & \\
- sangat kurus & 5 & 5,6 \\
- kurus & 6 & 6,7 \\
- normal & 62 & 68,9 \\
- gemuk & 17 & 18,9 \\
BB/U & & \\
- gizi buruk & 12 & 13,3 \\
- gizi kurang & 11 & 12,2 \\
- gizi baik & 66 & 73,3 \\
- gizi lebih & 1 & 1,1 \\
TB/U & & \\
-sangat pendek & 35 & 38,9 \\
- pendek & 11 & 12,2 \\
- normal & 41 & 45,6 \\
- tinggi & 3 & 3,3 \\
BB/TB & & \\
- sangat kurus & 1 & 1,1 \\
- kurus & 10 & 11,1 \\
- normal & 71 & 78,9 \\
- gemuk & 8 & 8,9 \\
\hline
\end{tabular}

\section{Hasil Uji Korelasi Spearman}

Berdasarkan hasil uji statistik, hubungan status gizi (IMT/U) dengan penyakit infeksi didapatkan nilai koefisien korelasi (r) sebesar 0,046 dan nilai $\mathrm{p}=$ 0,668, $\alpha=0,05$ (Tabel 5). Hal ini menunjukkan tidak terdapat hubungan status gizi (IMT/U) dengan penyakit infeksi pada anak umur 1- 3 tahun di Desa Mopusi Kecamatan Loloyan Kabupaten Bolaang Mongondow Induk.

Tabel 5. Hubungan antara Status Gizi dengan Penyakit Infeksi

\begin{tabular}{|c|c|c|}
\hline Variabel penelitian & $r$ & $p$ \\
\hline Status Gizi (IMT/U) & \multirow{2}{*}{0,046} & \multirow{2}{*}{0,668} \\
\hline Penyakit infeksi & & \\
\hline Status Gizi (BB/U) & \multirow{2}{*}{$-0,118$} & \multirow{2}{*}{0,268} \\
\hline Penyakit infeksi & & \\
\hline Status Gizi (TB/U) & \multirow{2}{*}{0,59} & \multirow{2}{*}{0,580} \\
\hline Penyakit infeksi & & \\
\hline Status Gizi (BB/TB) & \multirow{2}{*}{0,095} & \multirow{2}{*}{0,372} \\
\hline Penyakit infeksi & & \\
\hline
\end{tabular}

Berdasarkan hasil uji statistik, hubungan status gizi (BB/U) dengan penyakit infeksi didapatkan nilai (r) sebesar $-0,118$ dan nilai $\mathrm{p}=0,268<\alpha=0,05$ yang menunjukkan bahwa tidak terdapat hubungan status gizi (BB/U) dengan penyakit infeksi pada anak umur 1-3 tahun di Desa Mopusi Kecamatan Loloyan Kabupaten Bolaang Mongondow Induk.

Berdasarkan hasil uji statistik, hubungan status gizi (TB/U) dengan penyakit infeksi didapatkan nilai (r) sebesar 0,59 dan nilai $\mathrm{p}=0,580<\alpha=0,05$ yang menunjukkan bahwa tidak terdapat hubungan status gizi (TB/U) dengan penyakit infeksi ibu pada anak umur 1-3 tahun di Desa Mopusi Kecamatan LolayanKabupaten Bolaang Mongondow Induk.

Berdasarkan hasil uji statistik, hubungan status gizi (BB/TB) dengan penyakit infeksi didapatkan nilai (r) sebesar 0,095 dan nilai $\mathrm{p}=0,372<\alpha=0,05$ yang menunjukkan bahwa tidak terdapat hubungan status gizi (BB/TB) dengan 
penyakit infeksi pada anak umur 1- 3 tahun di Desa Mopusi Kecamatan Loloyan Kabupaten Bolaang Mongondow Induk.

\section{BAHASAN}

Penelitian ini dilaksanakan pada bulan November-December 2014 di Desa Mopusi Kecamatan Lolayan Kabupaten Bolaang Mongondow. Sampel penelitian yaitu anak umur 1-3 tahun yang berjumlah 90 anak.

Riwayat penyakit infeksi dalam penelitian ini yaitu riwayat penyakit ISPA, diare dan pneumonia yang terjadi pada 90 batita di desa Mopusi. Dengan pembagian kategori yaitu iya bagi batita yang positif mengalami penyakit ISPA, diare dan pneumoni $>2$ x dalam satu bulan terakhir. Sebaliknya masuk dalam kategori tidak bila batita tidak mengalami riwayat penyakit ISPA, diare atau pneumoni $>2$ kali dalam satu bulan terakhir. Dalam penelitian tidak didapatkan batita yang memiliki riwayat penyakit pneumoni dalam satu bulan terakhir, dan untuk itu riwayat pneumoni dalam penelitian ini disangkal.

Setelah melakukan pengujian statistik didapatkan data riwayat penyakit infeksi pada anak dalam 1 bulan terakhir sebanyak 26 batita (28,9\%) masuk kategori iya dan sebanyak 64 batita $(71,1 \%)$ masuk dalam kategori tidak dengan frekuensi sebanyak 13 dari total 38 anak laki-laki yang memiliki riwayat penyakit infeksi sedangkan untuk anak perempuan didapatkan 12 dari total 52 anak perempuan dengan riwayat penyakit infeksi dimana laki-laki sebanyak 38 batita (42,2\%) dan perempuan sebanyak 52 batita (57,8\%). Jenis kelamin merupakan faktor internal yang menentukan kebutuhan gizi sehingga ada keterkaitan antara jenis kelamin dengan keadaan gizi batita.

Masalah gizi pada anak usia ini sesuai dengan penelitian yang dilakukan oleh Turnip (2008) yang menyatakan bahwa anak usia 12-24 bulan berada pada masa perkembangan kritis terutama perkembangan otak, sehingga membutuhkan zat gizi yang baik, namun karena berbagai masalah mengakibatkan timbulnya berbagai masalah gizi pada anak.
Hasil penelitian mengenai hubungan antara riwayat penyakit infeksi dan status gizi pada batita di Desa Mopusi Kecamatan Loloyan Kabupaten Bolaang Mongondow Induk memperlihatkan tidak terdapat hubungan status gizi (IMT/U), (BB/U), (TB/U) dengan penyakit infeksi pada anak umur 1-3 tahun.

\section{SIMPULAN}

Dari hasil penelitian dapat disimpulkan bahwa di Desa Mopusi Kecamatan Loloyan Kabupaten Bolaang Mongondow Induk sebagian besar batita menunjukkan status gizi IMT/U termasuk kategori normal.

Tidak terdapat hubungan status gizi (IMT/U, BB/U, TB/U, dan BB/TB) dengan penyakit infeksi pada anak umur 1-3 tahun di Desa Mopusi Kecamatan Loloyan Kabupaten Bolaang Mongondow Induk.

\section{SARAN}

Disarankan ibu batita untuk lebih meningkatkan pengetahuan gizi agar tercapai status gizi batita yang baik, dan selalu memantau status gizi batita dengan cermat. Juga disarankan para tenaga kesehatan untuk lebih meningkatkan penyuluhan tentang gizi batita dan penyakit infeksi khususnya pada batita.

\section{DAFTAR PUSTAKA}

1. Almatsier S. Prinsip Dasar Ilmu Gizi. Jakarta: Gramedia, 2001; p. 3-4.

2. Irawati Y. Hubungan antara Riwayat Infeksi dan Pengetahuan Gizi Ibu dengan Status Gizi Balita di Puskesmas Jatibarang Brebes. [cited 2015 Feb 2]. Semarang: Universitas Muhammadiyah Semarang, 2007.

3. Rusilanti. Menu Sehat untuk Balita. Jakarta: Kawan Pustaka, 2006; p. 12.

4. Adiningsih S. Waspadai Gizi Balita Anda. Jakarta: Elex Media Komputindo, 2010; p. 37.

5. Rusilanti, Dahlia M. Variasi Bubur Susu untuk Anak. Jakarta: Agro Media, 2008; p. 22.

6. Meadow R, Newell S. Lecture notes. Pediatrika (Edisi ke-7). Jakarta: Erlangga, 2005; p. 233. 